point, with justifiable surprise, to the committee's formal endorsement (in its letter for general circulation) for courses of study intended to foster closer relationships between students and industry and the presence of at least three former colleges of advanced technology ("universities in waiting" in the early 1960s) among those now worst hit (Salford, Aston in Birmingham and Bradford).

The delivery of the committee's letters to universities comes at an awkward time, with the summer vacation almost everywhere begun. The committee has agreed that aggrieved universities should have a right of "consultation", which will, nevertheless, have to be exercised quickly. The committee of Vice-Chancellors and Principals is hoping within the week to put together a document showing how the pattern of the university system will be changed, but even that calculation will be jeopardized by uncertainty about the recruitment of overseas students (who pay higher fees) in the next few years. Even moderately gloomy forecasts suggest that the total reduction of university income may be as much as 17 per cent when allowance is made for that deprivation.

\section{French universities}

\section{New appointments}

While Mrs Margaret Thatcher squeezes the British universities, the departure of another lady over the channel has French universities sighing with relief. Madam Saunier-Seîté, Minister of the Universities under President Giscard d'Estaing, set out to centralize power over appointments and the allocation of degrees, and to weaken the role of some of the smaller regional universities. Now, under a gentlemanly new minister of the new government, $M$. Alain Savary, that is being reversed.

M. Savary says he wants dialogue with the universities, and dialogue he seems bound to get. Within a few days of the election of President Mitterrand, 100 lecturers at the University of Paris signed a declaration condemning the previous minister's "scandalous" methods of making university appointments and demanding a more democratic approach. The two principal education unions, the Syndicat National de l'Enseignement Supérieur and the Syndicat Général de l'Education Nationale, also weighed in with a joint statement warning that conservative and technocratic forces were still in control of the universities, and that they would have to be overthrown.

The chief target seems to be the Conseil Supérieur des Corps Universitaires, which according to its timetable should meet this month to consider this year's new appointments to the few university posts available. The council, strengthened by SaunierSeîté, interviews candidates and makes its decisions in private, without right of appeal, complain the Paris 100; moreover its council is said to be predominantly conservative and to give a poor hearing to candidates offering a novel approach to teaching or unfamiliar combinations of subjects. Certainly, the council - as now constituted - is an obstacle to university autonomy, and M. Savary, while not referring to it directly, has said he wishes to restore university autonomy and to set up new decision-making methods which will be "very decentralized".

On another tack, Savary also seems set to restore some of the second and third-level degree courses whose status as such was removed by the previous minister. A partial list of approved courses for 1981-82 was released last week. It was determined almost entirely by assessment procedures set in train the previous year and, conscious of its shortcomings, M. Savary has announced that the universities are free to appeal against the decisions (where a course has been cancelled) or to make new proposals. But he has called for "a sense of self-discipline" among the professors: there is not to be a free-for-all in which every wild proposal will meet approval.

Savary also says that appeals may not last into next year. The device is a stop-gap measure. For the long term, M. Savary plans to enter "without delay" into discussions, with all who are interested, over new mechanisms for the accreditation of courses.

Robert Walgate

\section{US biomedical research}

\section{Against the tide}

\section{Washington}

Democrats in the House of Representatives have been having little success in trying to reverse budget cuts proposed by President Ronald Reagan, but they may gain a rare victory on the issue of support for biomedical research training.

Focus of the dispute is the National Research Service Awards (NRSA) scheme, which provides about 10,000 grants annually to support postgraduate and postdoctoral research workers. The Reagan Administration is proposing that such grants should no longer contain institutional support to cover general overheads at research institutions, which would mean a cut of more than 25 per cent in grant allocation. Medical schools and universities complain that without this support - about $\$ 50$ million a year - they will not be able to sustain an adequate base across all areas of research training.

The medical schools won a preliminary round earlier this year, when both houses of Congress rejected the Administration's proposal to drop institutional support provided through the awards scheme as a budget saving for the fiscal year 1981, which began last October.

Less expected was their success in the debate on the 1982 budget in the House. The defection of a number of conservative Democrats to the Senate side resulted in defeat for proposals submitted by the House leadership, and victory for amendments presented by Republicans.

For example, the House Science and Technology Committee had proposed deleting funds for the construction of the liquid metal fast breeder reactor at Clinch River in Tennessee, transferring much of this money to research in solar energy and conservation. The full House, however, rejected this proposal, restoring the Clinch River funds and severely reducing the solar energy budget.

In biomedical research training, however, the cuts proposed for 1982 brought a stream of protests from the research community. In a letter to Representative John D. Dingell, chairman of the House Energy and Commerce Committee which has responsibility for the budget of the National Institutes of Health, 58 separate medical and research associations warned that the cuts would be "severely harmful".

The lobbying seemed to pay off. $\mathrm{Mr}$ Dingell's committee recommended to the full House that the NRSA budget be raised to $\$ 194$ million from the proposed $\$ 147.3$ million.

The Republican-run Senate, however, has already passed a budget bill containing the lower figure proposed by Mr Reagan. In addition, the Senate suggests an upper limit on biomedical research supported by the National Institutes of Health of $\$ 3.7$ million, a move which the medical associations describe in their letter as "arbitrary, unprecedented and unnecessary."

Negotiations now have to take place between the House and the Senate before both sides can agree on a common bill. At the same time, there is a parallel debate going on over the budget for the Department of Health and Human Services which is responsible for the funding of the National Institutes of Health.

In particular a key Senate Committee Labor and Human Resources - is in deadlock. The committee's previous chairman, Democrat Senator Edward Kennedy, backed by other Democrats and two Republicans, is proposing an additional $\$ 50$ million for research training awards. The current chairman, Republican Senator Orrin Hatch, is opposed to the committee taking a public stance in defiance of the President's recommendations; but he has promised that if the committee approves the lower figure, he will intervene to see if it can be raised.

Medical school lobbyists, such as the American Association of Medical Colleges, intend to keep up the pressure to have the funds restored. Dr LamontHavers of the Massachusetts General Hospital told a meeting of the American Association for the Advancement of Science that the proposed cuts reflected "a deep bias within the Office of Management and Budget" against the biomedical research training programme.

David Dickson 